\title{
Kohesivitas Kelompok Sebagai Pemoderasi Pengaruh Partisipasi Penganggaran, Asimetri Informasi, dan Self Esteem Pada Senjangan Anggaran
}

\author{
Nyoman Putra Yuna Aditya ${ }^{1}$ \\ Made Gede Wirakusuma ${ }^{2}$ \\ ${ }^{1,2}$ Fakultas Ekonomi dan Bisnis Universitas Udayana (Unud), Bali, Indonesia \\ e-mail: putra.yuna13@gmail.com
}

\begin{abstract}
ABSTRAK
Aktivitas penganggaran dilakukan sebagai alat ukur kinerja manajer, cenderung terdapat ketidaksesuaian antara yang dianggarkan dengan realisasi seperti yang dinyatakan oleh beberapa pimpinan BPR yang terdapat di kota Denpasar. Tujuan penelitian ini adalah untuk mendapatkan bukti empiris pengaruh kohesivitas kelompok dalam memoderasi pengaruh partisipasi anggaran, asimetri informasi, dan self esteem terhadap senjangan anggaran. Populasi pada penelitian ini adalah seluruh pejabat atau pegawai yang terlibat dalam proses penyusun anggaran pada 21 BPR di Kota Denpasar. Sampel diambil dengan menggunakan teknik purposive sampling. Teknik analisis yang digunakan adalah Moderated Regression Analysis (MRA). Berdasarkan hasil penelitian menunjukkan bahwa kohesivitas kelompok tidak mampu memoderasi pengaruh partisipasi anggaran pada senjangan anggaran, namun kohesivitas kelompok secara statistik mampu memoderasi pengaruh asimetri informasi dan self esteem pada senjangan anggaran di BPR se-Kota Denpasar.
\end{abstract}

Kata kunci: Partisipasi anggaran, asimetri informasi, self esteem, senjangan anggaran.

\begin{abstract}
Budgeting activities are carried out as a measure of manager's performance, there tends to be a discrepancy between the budgeted and realized as stated by several BPR leaders in the city of Denpasar. The purpose of this study was to obtain empirical evidence of the influence of group cohesiveness in moderating the effect of budget participation, information asymmetry, and self esteem on budgetary slack. The population in this study were all officials or employees involved in the budgeting process for 21 BPR in Denpasar City. Samples were taken using purposive sampling technique. The analysis technique used is Moderated Regression Analysis (MRA). Based on the results of the study, group cohesiveness was not able to moderate the effect of budgetary participation on budgetary slack, but group cohesiveness was statistically able to moderate the influence of information asymmetry and self esteem on budgetary slack in rural banks throughout the city of Denpasar.
\end{abstract}

Keywords: Budget participation, information asymmetry, self esteem, budgetary slack.

\section{PENDAHULUAN}

Anggaran memegang peranan penting sebagai alat manajemen untuk

mengendalikan operasi perusahaan agar strategi yang ditetapkan dapat digunakan

untuk mencapai tujuan perusahaan. Sukarno (2000) menyatakan bahwa anggaran 
adalah rencana yang terorganisasi dan dinyatakan dalam unit moneter untuk operasi dan sumber daya suatu perusahaan selama periode tertentu di masa yang akan datang, sedangkan menurut Arthaswadaya (2015) mendefinisikan anggaran sebagai suatu perencanaan dan pengendalian dalam jangka pendek secara efektif dalam organisasi. Pengertian anggaran yang lain menurut Supriyono dalam penelitian Falikhatun (2008) menyatakan bahwa anggaran memiliki dua peranan penting yaitu sebagai perencanaan dan kriteria kinerja.

Anggaran sebagai perencanaan berisi tentang rencana-rencana keuangan organisasi di masa yang akan datang, sedangkan anggaran sebagai kriteria kinerja berfungsi sebagai bagian dari proses pengendalian manajemen yang dapat dinyatakan secara formal. Berdasarkan beberapa definisi anggaran diatas dapat disimpulkan bahwa anggaran merupakan cara untuk mengkomunikasikan rencana, mengelola sumber daya, menentukan tujuan dan sasaran, serta sebagai acuan penting dalam suatu organisasi.

Setiap manajemen menginginkan organisasi yang mereka kelola mencapai tujuan organisasi yang telah ditetapkan. Setiap anggota individu dalam organisasi pasti mempunyai tujuan pribadi yang tidak selalu konsisten dengan tujuan organisasi agar sebuah organisasi mempunyai keselarasan tujuan diperlukan adanya manajemen pengendalian yang baik untuk menyelarasan tujuan tersebut (Arthaswadaya, 2015). Salah satu cara organisasi melaksanakan pengendalian manajemen yang berkaitan dengan penyelarasan tujuan tersebut adalah dengan menggunakan sistem pengendalian yang bersifat formal yaitu penyusunan anggaran. 
Kegiatan pada proses penyusunan anggaran memiliki dampak langsung terhadap perilaku manusia, sehingga terdapat perilaku-perilaku manusia yang akan timbul sebagai akibat dari anggaran. Proses penyusunan anggaran perlu memperhatikan pihak-pihak yang terlibat dalam proses penyusunannya yaitu pihak atasan dan bawahan atau sering disebut dengan partisipasi anggaran (Winarni, 2014). Anggaran yang disusun pada perusahaan bertujuan agar manajer dapat menjalankan perusahaan secara efektif dan efisien, begitu juga dengan proses penyusunannya harus dibuat dengan teliti secara efektif dan efisien. Anggaran yang dibuat secara efektif akan mempengaruhi tercapainya tujuan perusahaan yang telah ditetapkan, sedangkan keefisienan anggaran berpengaruh terhadap tepatnya pengeluaran biaya yang dikeluarkan perusahaan agar tidak ada pemborosan dalam anggaran, sehingga suatu perusahaan harus membuat perencanaan yang matang sebelum memulai kegiatan operasionalnya untuk meminimalisasi kegagalan yang mungkin terjadi. Proses penganggaran dapat dilakukan dengan metode top down, bottom up dan partisipatif (semua terlibat dalam proses penyusunan anggaran).

Partisipasi anggaran adalah proses yang menggambarkan individu yang terlibat dalam proses penyusunan anggaran dan mempunyai pengaruh terhadap target anggaran (Brownell, 1982). Kecenderungan bawahan untuk melakukan senjangan anggaran selain dapat dijelaskan dengan faktor ekonomi seperti dalam teori agensi, juga dapat dijelaskan dengan faktor non ekonomi, seperti self esteem. Alasan dari penggunaan faktor non ekonomi adalah karena secara praktik, bawahan berprestasi tidak hanya termotivasi berdasarkan insentif moneter saja 
(faktor ekonomi), tetapi juga termotivasi oleh faktor lain secara kompleks misalnya faktor personal atau faktor sosial. Faktor-faktor ini termasuk kepuasan apabila dapat mengerjakan tugas dengan baik, pengakuan, dan tanggungjawab. Insentif moneter saja tidak cukup untuk mencapai tingkat motivasi tertentu dari bawahan.

Dalam kaitannya dengan budgetary slack pada proses penyusunan anggaran secara partisipatif, seorang manajer penyusun anggaran dengan self esteem yang rendah akan cenderung lebih tinggi dalam menciptakan senjangan. Self esteem yang tinggi memotivasi manajer penyusun anggaran untuk melakukan pekerjaannya dengan baik untuk menjaga konsistensi hasil evaluasi dirinya agar tetap baik, terlepas dari kondisi asimetri yang mereka peroleh.

Anggaran berfungsi sebagai perencana dan pengendali perusahaan. Disamping itu, diketahui pula dengan jelas bahwa anggaran memiliki hubungan dan dampak secara langsung bagi sikap perilaku manusia, yang terkadang membuat orang atau individu dalam suatu organisasi menjadi cemas dan tertekan sehingga pada kesempatan berpartisipasi dalam proses penyusunan anggaran, atasan akan memberi kewenangan kepada para manajer pusat pertanggungjawaban untuk menetapkan isi anggaran mereka. Kewenangan ini memberikan peluang bagi partisipan untuk menyalahgunakan kewenangan dan informasi yang mereka miliki yaitu dengan menyampaikan informasi yang bias terhadap atasannya (asimetri informasi) dengan tujuan mempermudah pencapaian anggaran. Hal ini tentu dapat merugikan organisasi karena para manajer cenderung akan menganggarkan pendapatan yang lebih rendah dan 
menganggarkan biaya yang lebih tinggi, sehingga menimbulkan senjangan anggaran (budgetary slack).

Fenomena budgetary slack dalam dunia nyata sering terjadi dan menimbulkan masalah serta kerugian yang besar terhadap organisasi. Salah satu contohnya adalah tentang indikasi terjadinya budget slack pada salah satu BPR di Kota Denpasar yang dapat dilihat pada Tabel 1. berikut.

\section{Tabel 1.}

Anggaran dan Realisasi Pendapatan Tahun Anggaran 2012-2017 Pada Salah Satu BPR di Kota Denpasar

\begin{tabular}{cccc}
\hline Tahun & $\begin{array}{c}\text { Potensi } \\
\text { Pendapatan } \\
(\mathrm{Rp})\end{array}$ & $\begin{array}{c}\text { Target } \\
\text { Pendapatan } \\
(\mathrm{Rp})\end{array}$ & $\begin{array}{c}\text { Senjangan } \\
\text { Anggaran } \\
(\%)\end{array}$ \\
\hline 2012 & $3,633,133,585$ & $2,042,091,096$ & 56.21 \\
2013 & $4,109,377,805$ & $2,529,976,147$ & 61.57 \\
2014 & $4,577,678,391$ & $2,920,416,697$ & 63.80 \\
2015 & $4,967,935,151$ & $3,041,266,607$ & 61.22 \\
2016 & $5,249,017,754$ & $3,041,195,258$ & 57.94 \\
2017 & $5,992,161,668$ & $3,398,472,278$ & 56.72 \\
\hline
\end{tabular}

Sumber: Data diolah (2018)

Berdasarkan Tabel 1. di atas mencerminkan adanya budget slack karena terlihat dari setiap tahunnya target pendapatan lebih rendah dibanding dengan potensi yang dimiliki. Indikasi dalam data historis ini semakin memperkuat budget slack yang diciptakan selama penyusunan anggaran (Syahrir, 2017). Perilaku slack tersebut terjadi karena hubungan agensi (hubungan atasanbawahan) menginginkan posisi yang relatif aman dan nyaman dalam melaksanakan tugas dan fungsinya. Sebagaimana dijelaskan dalam teori agensi mengenai bagaimana atasan mendelegasikan pekerjaan kepada bawahan dan bawahan melaksanakan tugas untuk mencapai kepentingan atasan, kemudian hubungan antara atasan dan bawahan menimbulkan masalah atau yang disebut agency problem. Permasalahan ini muncul karena adanya keterlibatan dua pihak, 
Nyoman Putra Yuna Aditya dan Made Gede Wirakusuma. Kohesivitas ...

yaitu atasan yang memiliki otoritas melakukan tindakan-tindakan untuk mengendalikan perilaku bawahan agar anggaran yang disusun memenuhi kepentingan dapat dipertanggungjawabkan dan bawahan yang menerima pendelegasian dari atasan untuk terlibat dalam penyusunan anggaran untuk menentukan anggaran yang sesuai dengan sasaran dan target yang ingin dicapai (Syahrir, 2017).

Penelitian mengenai budgetary slack telah banyak dilakukan sebelumnya, namun masih banyak ditemukan ketidakkonsistenan. Hasil penelitian Lowe and Shaw (1968), Young (1985) dan Lukka (1988) menunjukkan bahwa partisipasi penganggaran memiliki pengaruh positif dan dapat meningkatkan terjadinya budgetary slack, karena individu-individu berpartisipasi dalam penyusunan anggaran dan mempunyai pengaruh terhadap target anggaran dengan tujuan mencari kemudahan dalam pencapaian anggaran yang ditetapkan dan menginginkan penghargaan atas pencapaian target anggaran tersebut. Namun, beberapa penelitian lain menunjukkan hasil yang berbeda, dimana penelitian yang dilakukan oleh Onsi (1973), Camman (1976), Merchant (1985) dan Dunk (1993) mengungkapkan bahwa partisipasi dalam penyusunan anggaran dapat mengurangi budgetary slack, karena agen membantu memberikan informasi kepada prinsipal tentang prospek masa depan sehingga anggaran yang disusun menjadi lebih akurat. Adanya partisipasi dalam penganggaran ini diharapkan mampu membantu jalannya penganggaran agar mencapai hasil yang baik.

Penelitian mengenai asimetri informasi yang dilakukan Faruq (2013) menghasilkan simpulan bahwa asimetri informasi berpengaruh signifikan 
terhadap budgetary slack dan penelitian Paingga (2013) pun menyatakan bahwa asimetri informasi berpengaruh positif terhadap budgetary slack. Hasil tersebut tidak sama dengan hasil yang didapatkan oleh Pratiwi (2008), Anggraeni (2008) dan Wenny (2012) yang menyebutkan bahwa tidak terdapat pengaruh yang signifikan antara asimetri informasi dengan budgetary slack.

Self esteem berpengaruh negatif terhadap senjangan anggaran. Artinya semakin rendah self esteem yang ada, maka senjangan anggaran yang timbul akan semakin tinggi, dan begitu pula sebaliknya. Dalam penelitian Wenny (2012) menyebutkan bahwa self esteem memiliki pengaruh yang signifikan dan positif terhadap senjangan anggaran. Artinya, semakin tinggi self esteem maka semakin tinggi pula senjangan anggaran yang timbul, dan begitu juga sebaliknya.

Ketidakkonsistenan hasil penelitian tersebut yang melatarbelakangi penelitian ini untuk terus dilanjutkan. Govindarajan (1986) menyatakan bahwa perbedaan hasil dari penelitian sebelumnya bisa dipecahkan dengan menggunakan pendekatan kontinjensi. Hal tersebut dilakukan dengan cara memasukan variabel lain yang mungkin mempengaruhi hubungan partisipasi penganggaran, self esteem, dan asimetri informasi pada budgetary slack. Variabel yang diperkirakan dapat mempengaruhi hubungan partisipasi penganggaran, self esteem, dan asimetri informasi dengan budgetary slack tersebut adalah Kohesivitas kelompok. Karena tanda dari kelompok dengan kohesivitas tinggi adalah timbulnya rasa saling memiliki dan bertanggungjawab terhadap hasil usaha kelompoknya.

Group cohesiveness mampu memperlemah pengaruh partisipasi anggaran dan pengaruh asimetri informasi pada senjangan anggaran. Penelitian mengenai 
group cohesiveness pun dilakukan oleh Dwisariasih (2013) yang menghasilkan kesimpulan bahwa kohesivitas kelompok berpengaruh signifikan positif terhadap hubungan partisipasi anggaran dengan kesenjangan anggaran.

Tingkat kohesivitas bisa mempunyai akibat positif atau negatif tergantung seberapa baik tujuan kelompok sesuai dengan tujuan organisasi formal. Bila kohesivitas tinggi dan kelompok menerima serta sepakat dengan tujuan formal organisasi, maka perilaku kelompok akan positif ditinjau dari sisi organisasi formal. Tetapi bila kelompok sangat kohesif tetapi tujuannya tidak sejalan dengan organisasi formal, maka perilaku kelompok akan negatif ditinjau dari sisi organisasi formal (Robbins, 1996). Berkaitan dengan proses partisipasi penyusunan anggaran, apabila tujuan kelompok dengan kohesivitas yang tinggi sesuai dengan tujuan manajemen organisasi, maka perilaku kelompok terhadap organisasi akan positif dan cenderung untuk tidak menciptakan budgetary slack. Berdasarkan uraian diatas dapat dirumuskan hipotesis yaitu sebagai berikut:

$\mathrm{H}_{1}$ : Kohesivitas kelompok memoderasi pengaruh partisipasi anggaran pada senjangan anggaran.

Kim and Robert (2001) mendefinisikan kohesivitas kelompok sebagai tingkat yang menggambarkan suatu kelompok dengan anggota yang mempunyai pertalian dengan anggota lainnya dan berkeinginan untuk tetap menjadi bagian dari kelompok tersebut. Dalam pengaruh asimetri informasi pada budgetary slack pada konteks partisipasi anggaran, banyak teori yang mengatakan bahwa kohesivitas dalah teamwork. Tanda dari kelompok dengan kohesivitas adalah timbulnya rasa saling memiliki dan bertanggungjawab atas hasil usaha kelompoknya, sehingga membentuk komitmen pada diri masing-masing anggota. 
Apabila organisasi memiliki anggota dengan kohesivitas yang tinggi, tentu pada saat proses penyusunan anggaran mereka yang terlibat akan berusaha menyampaikan informasi terbaik yang mereka miliki dengan tujuan agar anggaran yang disusun dapat sesuai dengan kondisi dilapangan dan tidak mengganggu pengambilan keputusan di tahun anggaran berikutnya. Terbentuknya komitmen tentu akan membuat individu di dalam organisasi lebih mendahulukan kepentingan organisasi serta berusaha agar organisasi menjadi produktif dan profitable. Berdasarkan uraian diatas dapat dirumuskan hipotesis yaitu:

$\mathrm{H}_{2}$ : Kohesivitas kelompok memoderasi pengaruh asimetri informasi pada senjangan anggaran

Sharma dan Agarwala (2013) meyebutkan bahwa self esteem adalah kepercayaan diri seseorang, kepuasan diri terhadap suatu hal dan rasa menghormati diri sendiri. Hal tersebut meliputi keyakinan tentang kemampuan diri sendiri dan kelayakan. Seseorang dengan self esteem yang rendah cenderung tidak dapat bekerja dengan baik. Dengan mental seperti itu individu akan cenderung melakukan senjangan anggaran karena tidak percaya dengan kemampuannya sendiri sehingga berasumsi apakah anggaran yang dibuat dapat tercapai. Orang yang memiliki Self Esteem tinggi diharapkan mampu untuk mengurangi Senjangan Anggaran. Seseorang cenderung memandang dirinya begitu penting, berharga dan berpengaruh, maka timbul kepercayaan diri atas pekerjaan yang dilakukannya karena memiliki keyakinan bahwa apa yang dilakukannya akan berhasil dan menciptakan hasil yang optimal. 
Pemenuhan tingkat aspirasi individu lebih pada kinerjanya bukan pada tujuan pribadinya. Sehingga self esteem merupakan suatu keyakinan nilai diri sendiri berdasarkan evaluasi diri secara keseluruhan. Orang yang mempunyai self esteem tinggi cenderung memandang diri mereka sendiri sebagai seorang yang penting, berpengaruh, dan berharga dalam suatu pekerjaan yang mereka lakukan. Dengan demikian, jika seseorang merasa dirinya begitu penting, berharga, dan berpengaruh maka akan timbul kepercayaan diri atas pekerjaan yang dilakukannya karena apa yang dilakukannya berhasil dan menciptakan hasil yang optimal (Kreitner dan Kinicki, 2003). Dalam kaitannya dengan budgetary slack pada proses penyusunan anggaran secara partisipatif, seorang manajer penyusun anggaran dengan self esteem yang rendah akan cenderung lebih tinggi dalam menciptakan senjangan. Self esteem yang tinggi memotivasi manajer penyusun anggaran untuk melakukan pekerjaannya dengan baik untuk menjaga konsistensi hasil evaluasi dirinya agar tetap baik, terlepas dari kondisi asimetri yang mereka peroleh. Berdasarkan uraian diatas dapat dirumuskan hipotesis yaitu sebagai berikut:

$\mathrm{H}_{3}$ : Kohesivitas Kelompok memoderasi pengaruh Self Esteem pada Senjangan Anggaran

\section{METODE PENELITIAN}

Lokasi penelitian dilakukan di Bank Perkreditan Rakyat (BPR) yang berada di Kota Denpasar. Subjek dalam penelitian ini adalah para penyusun anggaran di BPR yang tersebar di Kota Denpasar sebanyak 21 BPR yang terdaftar di OJK. Adapun kerangka konsep dalam penelitian ini dilihat pada Gambar 1 berikut. 


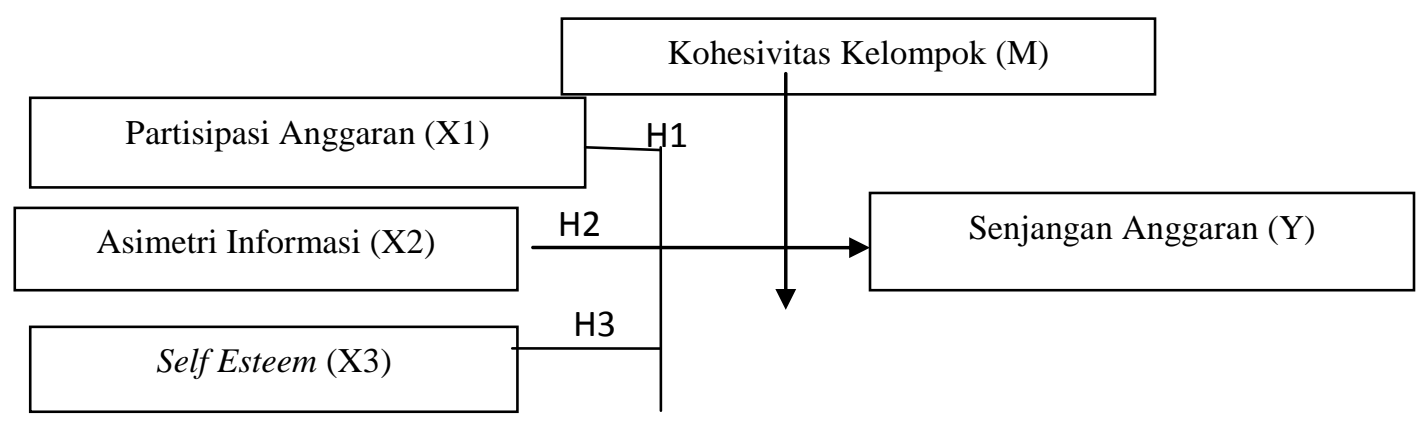

Sumber:

Gambar 1.Kerangka Konseptual

$\mathrm{H}_{1}$ : Dwisariasih (2013) dan (Robbins, 1996)

$\mathrm{H}_{2}$ : Kim and Robert (2001)

$\mathrm{H}_{3}$ : Sharma dan Agarwala (2013)

Keterangan:

$\mathrm{H}_{1}$ : Kohesivitas kelompok memoderasi pengaruh partisipasi anggaran pada senjangan anggaran

$\mathrm{H}_{2}$ : Kohesivitas kelompok memoderasi pengaruh asimetri informasi pada senjangan anggaran

$\mathrm{H}_{3}$ : Kohesivitas Kelompok memoderasi pengaruh Self Esteem pada Senjangan Anggaran

Variabel terikat dalam penelitian ini adalah senjangan anggaran. Senjangan anggaran (Y) diukur menggunakan indikator perbedaan jumlah anggaran yang dinyatakan dengan estimasi terbaik, kelonggaran dalam anggaran, standar anggaran dan keinginan untuk mencapai target. Variabel bebas dalam penelitan ini adalah partisipasi anggaran, asimetri informasi, dan self esteem yang masingmasing diukur dengan menggunakan indikator. Sedangkan variabel moderasi pada penelitian ini adalah kohesivitas kelompok.

Jenis data yang digunakan dalam penelitian ini adalah data kualitatif dan data kuantitatif. Data kualitatif berupa nama-nama BPR yang terdaftar di Kota Denpasar dan kuesinoner yang digunakan oleh peneliti. Data kuantitatif berupa 
skor jawaban kuesioner yang diperoleh dengan skala likert 4 point. Hasil jawaban kuesioner akan diberi nilai 4 poin untuk jawaban Sangat Setuju (SS), 3 poin untuk jawaban Setuju (S), 2 poin untuk jawaban Tidak Setuju (TS), dan 1 poin untuk jawaban Sangat Tidak Setuju (STS). Sedangkan sumber data yang digunakan dalam penelitian ini adalah data primer yaitu berupa jawaban responden terhadap item-item pertanyaan yang terdapat dalam lima instrumen penelitian yaitu partisipasi anggaran, senjangan anggaran, asimetri informasi, self esteem dan kohesivitas kelompok.

Populasi dalam penelitian ini adalah seluruh pejabat atau pegawai yang terlibat dalam proses penyusun anggaran pada 21 BPR di Kota Denpasar. Pengambilan sampel dalam penelitian ini dilakukan dengan menggunakan metode purposive sampling sehingga responden dalam penelitian ini dipilih sebanyak 5 orang manajer atau kepala bagian/divisi setingkat manajer. Sehingga jumlah kuesioner yang disebarkan di setiap BPR berjumlah 5 kuesioner. Sedangkan metode pengumpulan data yang digunakan dalam penelitian ini adalah metode survei berupa kuesioner. Kuesioner yang disebarkan berupa daftar pernyataan tertulis kepada responden mengenai partisipasi anggaran, asimetri informasi, self esteem, dan senjangan anggaran.

Teknik analisis data yang digunakan dalam penelitian ini adalah teknik analisis regresi linier berganda dengan moderasi. Persamaan moderated regression analysis sebagai berikut.

$\mathrm{Y}=\alpha+\beta_{1} \mathrm{X}_{1}+\beta_{2} \mathrm{X}_{2}+\beta_{3} \mathrm{X}_{3}+\beta_{4} \mathrm{M}+\beta_{5} \mathrm{X}_{1} \mathrm{M}+\beta_{6} \mathrm{X}_{2} \mathrm{M}+\beta_{7} \mathrm{X}_{3} \mathrm{M}+\mathrm{e}$ 


\section{Keterangan :}

\begin{tabular}{|c|c|}
\hline$Y$ & $=$ Senjangan Anggaran \\
\hline & $=$ Konstanta \\
\hline 1 & $=$ Partisipasi Anggaran \\
\hline$x_{2}$ & $=$ Asimetri Informasi \\
\hline$x_{3}$ & $=$ Self Esteem \\
\hline & $=$ Kohesivitas Kelompol \\
\hline 1. $\beta_{2 .} \beta_{3 .} \beta_{4 .} \beta_{5 .} \beta_{6 .} \beta$ & $\begin{array}{l}=\text { Koefisien regresi } \\
=\text { Standar error }\end{array}$ \\
\hline
\end{tabular}

Variabel moderasi dapat diklasifikasikan menjadi 4 jenis. Masing-masing klasifikasi moderasi dapat diidentifikasi sebagaimana contoh berikut, jika $\mathrm{X}$ adalah variabel predictor, $\mathrm{Y}$ variabel terikat dan $\mathrm{M}$ variabel moderasi maka persamaan regresi yang dapat dibentuk sebagai berikut :

$$
\mathrm{Y}=\beta_{1} \mathrm{X}_{1}+\beta_{2} \mathrm{M}_{1}+\beta_{3} \mathrm{X}_{1} * \mathrm{M}_{1}
$$

Sebelum dilakukan pengujian hipotesis, data terlebih dahulu diuji asumsi klasik. Hal ini dilakukan untuk menghindari terjadinya estimasi bias mengingat tidak semua data dapat diterapkan regresi. Pengujian asumsi klasik meliputi uji normalitas dan uji heteroskedastisitas.

\section{HASIL DAN PEMBAHASAN}

Data penelitian diperoleh dari hasil kuesioner yang telah disebarkan kepada responden penelitian sejumlah 138 orang pegawai BPR di Kabupaten Badung. Karakteristik responden meliputi usia, jenis kelamin, tingkat pendidikan dan masa kerja responden. Ringkasan mengenai karakteristik responden dapat dilihat pada Tabel 2. sebagai berikut. 
Tabel 2.

Karakteristik Pegawai BPR di Kota Denpasar

\begin{tabular}{|c|c|c|c|c|}
\hline No & Karakteristik & Klasifikasi & $\begin{array}{l}\text { Jumlah } \\
\text { Responden } \\
\text { (orang) }\end{array}$ & $\begin{array}{c}\text { Persentase } \\
\text { Responden } \\
(\%)\end{array}$ \\
\hline \multirow{2}{*}{1} & \multirow{2}{*}{ Jenis Kelamin } & Pria & 39 & 45,88 \\
\hline & & Wanita & 46 & 54,12 \\
\hline \multirow{5}{*}{2} & \multirow[t]{3}{*}{ Jumlah } & & 85 & 100 \\
\hline & & 18-28 Tahun & 36 & 42,35 \\
\hline & & 29-38 Tahun & 20 & 23,53 \\
\hline & & $>38$ Tahun & 29 & 34,12 \\
\hline & \multirow{2}{*}{ Jumlah } & & 85 & 100 \\
\hline \multirow{4}{*}{3} & & SMA & 16 & 18,82 \\
\hline & Jenjang Pendidikan & Diploma & 19 & 22,35 \\
\hline & Terakhir & Sarjana & 42 & 49,41 \\
\hline & & Pascasarjana & 8 & 9,41 \\
\hline \multirow{5}{*}{4} & \multirow[t]{2}{*}{ Jumlah } & & 85 & 100 \\
\hline & & $1-5$ tahun & 38 & 44,71 \\
\hline & Lama Kerja & 5-10 tahun & 20 & 23,53 \\
\hline & & $>10$ tahun & 27 & 31,76 \\
\hline & \multicolumn{2}{|l|}{ Jumlah } & 85 & 100 \\
\hline
\end{tabular}

Sumber : Data diolah, 2018

Tabel 2. menunjukkan jumlah pegawai pria sebanyak 39 orang atau sebesar 45,88 persen, sedangkan pegawai wanita sebanyak 46 orang atau 54,12 persen. Hal ini memberikan informasi bahwa lebih banyak pegawai wanita dibandingkan pegawai pria yang bekerja pada BPR di Kota Denpasar. Apabila dilihat dari segi usia, responden yang berusia 18-28 tahun sebanyak 36 orang atau sebesar 42,35 persen, responden yang berusia 29-38 tahun sebanyak 20 orang atau sebesar 23,53 persen, dan responden yang berusia lebih dari 38 tahun sebanyak 29 orang atau sebesar 34,12 persen. Hal ini menunjukkan bahwa pegawai yang bekerja pada BPR di Kota Denpasar mayoritas adalah yang berusia 18-28 tahun.

Tabel 2. menunjukkan mayoritas pegawai BPR di Kota Denpasar adalah kelompok responden dengan tingkat pendidikan akhir Sarjana yaitu sebanyak 42 orang atau 49,41 persen, kemudian responden dengan tingkat pendidikan Diploma 
sebanyak 19 orang atau 22,35 persen, responden dengan tingkat pendidikan SMA sebanyak 16 orang atau 18,82 persen dan Pascasarjana sebanyak 8 orang atau 9,41 persen. Informasi ini memberikan gambaran bahwa pegawai BPR di Kota Denpasar paling dominan adalah lulusan Sarjana yang dianggap sudah mampu serta memadai untuk menjadi pegawai BPR yang memiliki kompetensi untuk mencapai tujuan organisasi.

Pengelompokkan responden berdasarkan lama bekerja menunjukkan bahwa responden yang bekerja selama 1 sampai 5 tahun adalah sebanyak 38 orang atau 44,71 persen, kemudian responden yang bekerja selama 5 sampai 10 tahun sebanyak 20 orang atau 23,53 persen, sedangkan yang bekerja lebih dari 10 tahun sebanyak 27 orang atau 31,76 persen. Hal ini mengindikasikan bahwa sebagian besar pegawai BPR di Kota Denpasar yang menjadi responden dalam penelitian ini memiliki masa kerja 1 sampai 5 tahun dan tidak sedikit pula pegawai yang bekerja selama lebih dari 10 tahun. Hal tersebut menunjukkan bahwa pegawai BPR di Kota Denpasar memiliki komitmen yang cukup tinggi karena mampu bertahan bekerja di BPR hingga mencapai lebih dari 10 tahun.

Suatu instrumen dikatakan valid apabila memiliki koefisien korelasi antara butir dengan skor total dalam instrumen tersebut lebih besar dari 0,30 dengan tingkat kesalahan Alpha 0,05. Hasil rekapitulasi uji validitas dalam penelitian ini disajikan dalam Tabel 3. sebagai berikut. 
Tabel 3.

Rekapitulasi Hasil Uji Validitas Instrumen Penelitian

\begin{tabular}{|c|c|c|c|c|}
\hline Variabel & Indikator & Koefisien Korelasi & Sig. (2-tailed) & Keterangan \\
\hline \multirow{5}{*}{$\begin{array}{c}\text { Partisipasi anggaran } \\
\left(\mathrm{X}_{1}\right)\end{array}$} & $\mathrm{X}_{1.1}$ & 0,896 & 0,000 & Valid \\
\hline & $\mathrm{X}_{1.2}$ & 0,922 & 0,000 & Valid \\
\hline & $\mathrm{X}_{1.3}$ & 0,928 & 0,000 & Valid \\
\hline & $\mathrm{X}_{1.4}$ & 0,938 & 0,000 & Valid \\
\hline & $\mathrm{X}_{1.5}$ & 0,938 & 0,000 & Valid \\
\hline \multirow{7}{*}{$\begin{array}{l}\text { Asimetri informasi } \\
\qquad\left(\mathrm{X}_{2}\right)\end{array}$} & $\mathrm{X}_{1.6}$ & 0,826 & 0,000 & Valid \\
\hline & $\mathrm{X}_{2.1}$ & 0,749 & 0,000 & Valid \\
\hline & $\mathrm{X}_{2.2}$ & 0,803 & 0,000 & Valid \\
\hline & $\mathrm{X}_{2.3}$ & 0,772 & 0,000 & Valid \\
\hline & $\mathrm{X}_{2.4}$ & 0,781 & 0,000 & Valid \\
\hline & $\mathrm{X}_{2.5}$ & 0,850 & 0,000 & Valid \\
\hline & $\mathrm{X}_{2.6}$ & 0,636 & 0,000 & Valid \\
\hline \multirow{5}{*}{$\begin{array}{l}\text { Self Esteem } \\
\quad\left(\mathrm{X}_{3}\right)\end{array}$} & $X_{3.1}$ & 0,795 & 0,000 & Valid \\
\hline & $\mathrm{X}_{3.2}$ & 0,898 & 0,000 & Valid \\
\hline & $\mathrm{X}_{3.3}$ & 0,739 & 0,000 & Valid \\
\hline & $\mathrm{X}_{3.4}$ & 0,750 & 0,000 & Valid \\
\hline & $\mathrm{X}_{3.5}$ & 0,495 & 0,000 & Valid \\
\hline \multirow{11}{*}{$\begin{array}{c}\text { Kohesivitas } \\
\text { Kelompok (M) }\end{array}$} & $\mathrm{M}_{1}$ & 0,790 & 0,000 & Valid \\
\hline & $\mathrm{M}_{2}$ & 0,800 & 0,000 & Valid \\
\hline & $\mathrm{M}_{3}$ & 0,681 & 0,000 & Valid \\
\hline & $\mathrm{M}_{4}$ & 0,774 & 0,000 & Valid \\
\hline & $\mathrm{M}_{5}$ & 0,732 & 0,000 & Valid \\
\hline & $\mathrm{M}_{6}$ & 0,736 & 0,000 & Valid \\
\hline & $\mathrm{M}_{7}$ & 0,887 & 0,000 & Valid \\
\hline & $\mathrm{M}_{8}$ & 0,651 & 0,000 & Valid \\
\hline & $\mathrm{M}_{9}$ & 0,726 & 0,000 & Valid \\
\hline & $\mathrm{M}_{10}$ & 0,429 & 0,000 & Valid \\
\hline & $\mathrm{M}_{11}$ & 0,666 & 0,000 & Valid \\
\hline \multirow{4}{*}{$\begin{array}{l}\text { Kohesivitas } \\
\text { Kelompok (M) }\end{array}$} & $\mathrm{M}_{12}$ & 0,771 & 0,000 & Valid \\
\hline & $\mathrm{M}_{13}$ & 0,705 & 0,000 & Valid \\
\hline & $\mathrm{M}_{14}$ & 0,435 & 0,000 & Valid \\
\hline & $\mathrm{M}_{15}$ & 0,731 & 0,000 & Valid \\
\hline \multirow{8}{*}{$\begin{array}{c}\text { Senjangan anggaran } \\
\text { (Y) }\end{array}$} & $\mathrm{Y}_{1}$ & 0,422 & 0,000 & Valid \\
\hline & $\mathrm{Y}_{2}$ & 0,634 & 0,000 & Valid \\
\hline & $\mathrm{Y}_{3}$ & 0,671 & 0,000 & Valid \\
\hline & $\mathrm{Y}_{4}$ & 0,360 & 0,000 & Valid \\
\hline & $\mathrm{Y}_{5}$ & 0,552 & 0,000 & Valid \\
\hline & $\mathrm{Y}_{6}$ & 0,572 & 0,000 & Valid \\
\hline & $\mathrm{Y}_{7}$ & 0,701 & 0,000 & Valid \\
\hline & $\mathrm{Y}_{8}$ & 0,625 & 0,000 & Valid \\
\hline
\end{tabular}

Sumber : Data diolah, 2018 
Hasil uji validitas pada tabel 3. menunjukkan bahwa skor total seluruh item pernyataan lebih besar dari 0,30 dengan signifikansi kurang dari 0,05. Hal ini menunjukkan bahwa butir-butir pernyataan dalam instrument penelitian tersebut valid dan layak digunakan sebagai instrument penelitian.

Uji Reliabilitas terhadap instrumen penelitian ini menggunakan nilai Alpha Cronbach, nilai Alpha Cronbach dinyatakan reliabel jika nilainya lebih besar atau sama dengan 0,60 .

Tabel 4.

Rekapitulasi Hasil Uji Reliabilitas Instrumen Penelitian

\begin{tabular}{clcc}
\hline No. & \multicolumn{1}{c}{ Variabel } & Cronbach's Alpha & Keterangan \\
\hline 1 & Partisipasi anggaran $\left(\mathrm{X}_{1}\right)$ & 0,816 & Reliabel \\
2 & Asimetri informasi $\left(\mathrm{X}_{2}\right)$ & 0,792 & Reliabel \\
3 & Self Esteem $\left(\mathrm{X}_{3}\right)$ & 0,789 & Reliabel \\
4 & Kohesivitas kelompok $(\mathrm{M})$ & 0,763 & Reliabel \\
5 & Senjangan anggaran $(\mathrm{Y})$ & 0,737 & Reliabel \\
\hline
\end{tabular}

Hasil uji reliabilitas yang disajikan dalam Tabel 4. menunjukkan bahwa seluruh instrumen penelitian memiliki koefisien Cronbach's Alpha lebih dari 0,60. Jadi dapat dinyatakan bahwa seluruh variabel telah memenuhi syarat reliabilitas atau kehandalan.

Analisis statistik deskriptif dipergunakan untuk menggambarkan atau menjelaskan suatu data pada variabel penelitian berdasarkan jumlah sampel, nilai rata-rata (mean), standar deviasi, nilai maksimum, dan nilai minimum.

Tabel 5.

Hasil Statistik Deskriptif Variabel Penelitian

\begin{tabular}{lrrrrr}
\hline & $N$ & Minimum & Maximum & Mean & Std. Deviation \\
\hline Partisipasi Anggaran & 85 & 6 & 24 & 15.93 & 4.197 \\
Asimetri Informasi & 85 & 12 & 24 & 16.62 & 2.936 \\
Self Esteem & 85 & 11 & 20 & 15.11 & 2.231 \\
Kohesivitas Kelompok & 85 & 40 & 60 & 47.87 & 4.942 \\
Senjangan Anggaran & 85 & 16 & 32 & 21.68 & 2.633 \\
Valid N (listwise) & 85 & & & & \\
\hline
\end{tabular}

Sumber : Data diolah, 2018 
Berdasarkan hasil uji statistik deskriptif pada Tabel 5. dapat diketahui bahwa total sampel yang digunakan adalah sebanyak 85 orang responden. Hasil statistik deskriptif masing-masing dalam penelitian ini dapat dijelaskan yaitu variabel partisipasi anggaran memiliki nilai minimum sebesar 6 dan nilai maksimum sebesar 24, memiliki nilai rata-rata sebesar 15,93, dengan nilai standar deviasi sebesar 4,197. Variabel asimetri informasi memiliki nilai minimum sebesar 12 dan nilai maksimum sebesar 24, memiliki nilai rata-rata sebesar 16,62 dengan nilai standar deviasi sebesar 2,936. Variabel Self Esteem memiliki nilai minimum sebesar 11 dan nilai maksimum sebesar 20, memiliki nilai rata-rata sebesar 15,11, dengan nilai standar deviasi sebesar 2,231. Variabel kohesivitas kelompok memiliki nilai minimum sebesar 40 dan nilai maksimum sebesar 60 , memiliki nilai rata-rata sebesar 47,87 dengan nilai standar deviasi sebesar 4,942. Variabel senjangan anggaran memiliki nilai minimum sebesar 16 dan nilai maksimum sebesar 32, memiliki nilai rata-rata sebesar 21,68, dengan nilai standar deviasi sebesar 2,633.

Uji normalitas menggunakan uji Kolmogorov-Smirnov, dengan uji ini dapat diketahui data yang digunakan berdistribusi normal atau tidak. Apabila Sign t hitung $>0.05$, maka data tersebut berdistribusi normal dan begitu juga sebaliknya (Santoso, 2001). 
Tabel 6.

Hasil Uji Normalitas

\begin{tabular}{llr}
\hline & & Unstandardized Residual \\
\hline $\mathrm{N}$ & & 85 \\
Normal Parameters & Mean & 0,0000000 \\
& Std. Deviation & 1,86604237 \\
Most Extreme Differences & Absolute & 0,079 \\
& Positive & 0,079 \\
& Negative & $-0,039$ \\
Kolmogorov-Smirnov Z & & 0,727 \\
Asymp. Sig. (2-tailed) & & 0,665 \\
\hline Sumber : Data diolah, 2018 & &
\end{tabular}

Berdasarkan Tabel 6. didapat nilai signifikansi sebesar 0,665, oleh karena nilai signifikansi uji Kolmogorov-Smirnov lebih dari 0,05 maka dapat disimpulkan bahwa model persamaan regresi tersebut berdistribusi normal.

Uji Heterokedastisitas dilakukan untuk menguji apakah dalam model regresi terjadi ketidaksamaan varian dari residu satu pengamatan ke pengamatan lain. Jika probabilitas signifikansinya di atas 0,05 maka dapat dikatakan bahwa pada model regresi tidak mengandung masalah heterokedastisitas. Pada Tabel 7. dapat dilihat bahwa nilai signifikansi dari masing-masing variabel lebih besar dari 0,05 yang berarti tidak terdapat pengaruh antara variabel bebas terhadap absolute residual. Dengan demikian, model yang dibuat tidak mengandung gejala heteroskedastisitas.

Tabel 7.

Hasil Uji Heteroskedastisitas

\begin{tabular}{clcl}
\hline No & \multicolumn{1}{c}{ Variabel Bebas } & Signifikansi & Keterangan \\
1 & Partisipasi anggaran $\left(\mathrm{X}_{1}\right)$ & 0,532 & Bebas heteros \\
2 & Asimetri informasi $\left(\mathrm{X}_{2}\right)$ & 0,239 & Bebas heteros \\
3 & Self Esteem $\left(\mathrm{X}_{3}\right)$ & 0,519 & Bebas heteros \\
4 & Kohesivitas kelompok $(\mathrm{M})$ & 0,915 & Bebas heteros \\
5 & Interaksi X1.M & 0,449 & Bebas heteros \\
6 & Interaksi X2.M & 0,249 & Bebas heteros \\
7 & Interaksi X3.M & 0,369 & Bebas heteros \\
\hline
\end{tabular}

Sumber : Data diolah, 2018 
Perhitungan koefisien regresi moderasi dilakukan dengan analisis regresi melalui software SPSS 18.0, diperoleh hasil yang ditunjukan pada Tabel 8.

Tabel 8.

Hasil Analisis Regresi Moderasi

\begin{tabular}{|c|c|c|c|c|c|}
\hline \multirow[t]{2}{*}{ Model } & \multicolumn{2}{|c|}{$\begin{array}{c}\text { Unstandardized } \\
\text { Coefficients }\end{array}$} & \multirow{2}{*}{$\begin{array}{c}\text { Standardized } \\
\text { Coefficients }\end{array}$} & \multirow[b]{2}{*}{$\mathrm{t}$} & \multirow[b]{2}{*}{ Sig. } \\
\hline & $\mathrm{B}$ & Std. Error & & & \\
\hline 1 (Constant) & 11,099 & 2,478 & & 4,480 & 0,000 \\
\hline Partisipasi Anggaran & 0,198 & 0,231 & 0,316 & 0,858 & 0,394 \\
\hline Asimetri Informasi & $-0,625$ & 0,282 & $-0,696$ & $-2,219$ & 0,029 \\
\hline Self Esteem & 0,794 & 0,247 & 0,672 & 3,209 & 0,002 \\
\hline Kohesivitas Kelompok & 0,083 & 0,058 & 0,156 & 1,421 & 0,159 \\
\hline $\mathrm{X} 1 . \mathrm{M}$ & $-0,002$ & 0,005 & $-0,235$ & $-0,448$ & 0,655 \\
\hline $\mathrm{X} 2 . \mathrm{M}$ & 0,023 & 0,007 & 2,292 & 3,465 & 0,001 \\
\hline X3.M & $-0,020$ & 0,006 & $-1,772$ & $-3,081$ & 0,003 \\
\hline R Square & & & & & 0,498 \\
\hline Adjusted R Square & & & & & 0,452 \\
\hline F Statistik & & & & & 10,903 \\
\hline Signifikansi & & & & & 0,000 \\
\hline
\end{tabular}

Berdasarkan hasil analisis regresi moderasi seperti yang disajikan pada Tabel 8. maka persamaan strukturalnya adalah sebagai berikut :

$$
\mathrm{Y}=0,198 \mathrm{X}_{1}-0,625 \mathrm{X}_{2}+0,794 \mathrm{X}_{3}+0,083 \mathrm{M}-0,002 \mathrm{X}_{1} \mathrm{M}+0,023 \mathrm{X}_{2} \mathrm{M}-0,020 \mathrm{X}_{3} \mathrm{M}+\mathrm{e}
$$

Nilai koefisien variabel interaksi dalam penelitian ini menunjukkan arah yang berlawanan dengan variabel bebas. Hal ini mengindikasikan bahwa variabel moderasi memperlemah pengaruh $\mathrm{X}$ terhadap $\mathrm{Y}$. Jika $\beta_{1}, \beta_{2}, \beta_{3}$ positif signifikan atau tidak dan $\beta_{5}, \beta_{6}, \beta_{7}$ positif signifikan, maka $M$ sebagai variabel moderating yang memperkuat pengaruh $\mathrm{X}$ terhadap Y. Jika $\beta_{1}, \beta_{2}, \beta_{3}$ negatif, signifikan atau tidak dan $\beta_{5}, \beta_{6}, \beta_{7}$ negatif signifikan, maka $M$ sebagai variabel moderating yang memperkuat pengaruh $\mathrm{X}$ terhadap $\mathrm{Y}$. Jika $\beta_{1}, \beta_{2}, \beta_{3}$ positif, signifikan atau tidak dan $\beta_{5}, \beta_{6}, \beta_{7}$ negatif signifikan, maka $M$ sebagai variabel moderating yang memperlemah pengaruh $\mathrm{X}$ terhadap $\mathrm{Y}$. Jika $\beta_{1}, \beta_{2}, \beta_{3}$ negatif, signifikan atau tidak 
dan $\beta_{5}, \beta_{6}, \beta_{7}$ positif signifikan, maka $\mathrm{M}$ sebagai variabel moderating yang memperlemah pengaruh $\mathrm{X}$ terhadap $\mathrm{Y}$.

Berdasarkan Tabel 8. menunjukkan bahwa koefisien determinasi yaitu nilai adjusted $\mathrm{R}^{2}$ adalah 0,452 . Ini berarti variasi senjangan anggaran dapat dipengaruhi secara signifikan oleh variabel partisipasi anggaran, asimetri informasi, Self Esteem, kohesivitas kelompok, interaksi $\mathrm{X}_{1} \cdot \mathrm{M}$, interaksi $\mathrm{X}_{2} \cdot \mathrm{M}$ dan interaksi $\mathrm{X}_{3} \mathrm{M}$ sebesar 45,2 persen, sedangkan sisanya sebesar 54,8 persen dijelaskan oleh faktorfaktor lain yang tidak dijelaskan dalam model penelitian.

Hasil uji F (Ftest) pada Tabel 9. menunjukkan bahwa nilai signifikansi $\mathrm{P}$ value 0,000 yang lebih kecil dari $\alpha=0,05$, ini berarti model yang digunakan pada penelitian ini adalah layak. Hasil ini memberikan makna bahwa seluruh variabel independen mampu memprediksi atau menjelaskan fenomena senjangan anggaran pada BPR di Kota Denpasar.

Tabel 9.

Hasil Uji F

\begin{tabular}{llccccc}
\hline Model & & Sum of Squares & df & Mean Square & F & Sig. \\
\hline 1 & Regression & 289.926 & 7 & 41.418 & 10.903 & $.000^{\mathrm{a}}$ \\
& Residual & 292.498 & 77 & 3.799 & & \\
& Total & 582.424 & 84 & & & \\
\hline
\end{tabular}

Sumber : Data diolah, 2018

Uji t dalam penelitian ini bertujuan untuk menguji apakah masing-masing variabel bebas $(\mathrm{X})$ yang digunakan dalam model regresi memiliki pengaruh pada variabel terikat $(\mathrm{Y})$. Apabila nilai signifikansinya $>0,05$ maka hipotesis ditolak (koefisien regresi tidak signifikan), dan apabila nilai signifikansi $\leq 0,05$ maka hipotesis diterima (koefisien regresi signifikan).

Berdasarkan hasil analisis regresi moderasi pada Tabel 9. menunjukkan bahwa variabel moderasi $\left(\beta_{4}\right)$ kohesivitas kelompok memiliki nilai yang lebih 
besar dari 0,05 yaitu dengan nilai signifikan 0,159 dan variabel interaksi antara partisipasi anggaran dengan kohesivitas kelompok $\left(\beta_{5}\right)$ juga memiliki nilai yang lebih besar dari 0,05 yaitu dengan nilai sebesar 0,655 hal ini berarti kohesivitas kelompok tidak dapat memoderasi pengaruh partisipasi anggaran pada senjangan $\operatorname{anggaran}\left(\mathrm{H}_{1}\right.$ ditolak).

Tingkat kohesivitas kelompok yang tinggi pada BPR di Kota Denpasar tidak dapat mempengaruhi hubungan partisipasi penganggaran pada senjangan anggaran (budgetary slack). Hal ini disebabkan karena responden dalam penelitian ini cenderung kurang berpartisipasi dalam penyusunan anggaran dan dominan responden tidak memiliki pengaruh yang besar dalam penetapan anggaran. Jadi walaupun sudah memiliki tingkat kohesivitas kelompok yang tinggi, namun karena responden memiliki partisipasi penyusunan anggaran yang rendah, maka hal tersebut tidak dapat mempengaruhi senjangan anggaran yang terjadi pada BPR di Kota Denpasar.

Apabila ditinjau dari karakteristik responden, maka menunjukkan bahwa responden dalam penelitian ini dominan berusia 18-28 tahun yang baru bekerja selama 1 sampai 5 tahun di BPR sehingga hal itu menunjukkan bahwa responden masih kurang berpartisipasi dalam penyusunan anggaran, sehingga tidak memiliki kontribusi besar dalam penyusunan anggaran, sehingga tidak dapat mempengaruhi senjangan anggaran yang terjadi dalam perusahaan.

Hasil penelitian ini tidak mendukung teori Robbins (1996) yang menyatakan semakin para anggota kelompok saling tertarik dan makin sepakat terhadap sasaran kelompok, maka akan semakin lekat atau semakin kohesif kelompok 
tersebut. Tingkat kohesivitas bisa mempunyai akibat positif atau negatif tergantung seberapa baik tujuan kelompok sesuai dengan tujuan organisasi formal. Bila kohesivitas tinggi dan kelompok menerima serta sepakat dengan tujuan formal organisasi, maka perilaku kelompok akan positif ditinjau dari sisi organisasi formal. Tetapi bila kelompok sangat kohesif tetapi tujuannya tidak sejalan dengan organisasi formal, maka perilaku kelompok akan negatif ditinjau dari sisi organisasi formal.

Berdasarkan hasil analisis regresi moderasi pada Tabel 9. menunjukkan bahwa variabel moderasi $\left(\beta_{4}\right)$ kohesivitas kelompok memiliki nilai yang lebih besar dari 0,05 yaitu dengan nilai signifikan 0,159 dan variabel interaksi antara asimetri informasi dengan kohesivitas kelompok $\left(\beta_{6}\right)$ memiliki nilai yang kurang dari 0,05 yaitu dengan nilai sebesar 0,001, hal ini berarti kohesivitas kelompok mampu memoderasi pengaruh asimetri informasi pada senjangan anggaran. Nilai koefisien regresi asimetri informasi $\left(\beta_{2}\right)$ negatif sebesar $-0,625$ dan nilai koefisien regresi variabel interaksi $\mathrm{X}_{2} \cdot \mathrm{M} \quad\left(\beta_{6}\right)$ positif sebesar 0,023 . Nilai tersebut menunjukkan arah yang berlawanan, maka disimpulkan bahwa variabel kohesivitas kelompok merupakan variabel moderasi yang memperlemah pengaruh asimetri informasi pada senjangan anggaran di BPR Kota Denpasar $\left(\mathrm{H}_{2}\right.$ diterima $)$.

Dengan adanya tingkat kohesivitas kelompok yang tinggi akan memperlemah dampak ketidakseimbangan informasi yang dimiliki bawahan dengan informasi yang dimiliki atasan, sehingga dapat meminimalisir terjadinya senjangan anggaran. Oleh karena itu, bagi para penyusun anggaran di BPR seKota Denpasar diharapkan dapat menyampaikan informasi yang sesungguhnya 
agar tidak ada informasi yang bias antara atasan dan bawahan, sehingga tujuan organisasi dapat tercapai.

Hasil penelitian ini didukung oleh pernyataan Kim dan Taylor (2001) yang menyebutkan bahwa kelompok dengan kohesivitas yang tinggi akan menumbuhkan rasa saling memiliki dan bertanggungjawab atas hasil usaha kelompoknya, sehingga membentuk komitmen pada diri masing-masing anggota. Apabila organisasi memiliki anggota dengan kohesivitas yang tinggi, tentu pada saat proses penyusunan anggaran partisipan yang terlibat akan berusaha menyampaikan informasi terbaik yang dimilikinya dengan tujuan agar anggaran yang disusun dapat sesuai dengan kondisi. dilapangan dan tidak mengganggu pengambilan keputusan di tahun anggaran berikutnya. Terbentuknya komitmen akan membuat individu di dalam organisasi lebih mementingkan kepentingan organisasi dan berupaya agar organisasi jadi lebih produktif serta profitable.

Berdasarkan hasil analisis regresi moderasi pada Tabel 9. menunjukkan bahwa variabel moderasi $\left(\beta_{4}\right)$ kohesivitas kelompok memiliki nilai yang lebih besar dari 0,05 yaitu dengan nilai signifikan 0,159 dan variabel interaksi antara self esteem dengan kohesivitas kelompok $\left(\beta_{7}\right)$ memiliki nilai yang kurang dari 0,05 yaitu dengan nilai sebesar 0,003 , hal ini berarti kohesivitas kelompok mampu memoderasi pengaruh self esteem pada senjangan anggaran. Nilai koefisien regresi self esteem $\left(\beta_{2}\right)$ positif sebesar 0,794 dan nilai koefisien regresi variabel interaksi $X_{3} \cdot M\left(\beta_{7}\right)$ negatif sebesar -0,020. Nilai tersebut menunjukkan arah yang berlawanan, maka disimpulkan bahwa variabel kohesivitas kelompok merupakan 
variabel moderasi yang memperlemah pengaruh self esteem pada senjangan anggaran di BPR Kota Denpasar $\left(\mathrm{H}_{3}\right.$ diterima $)$.

Tingkat kohesivitas kelompok yang tinggi akan membuat karyawan semakin percaya diri dan memiliki tanggungjawab yang tinggi, sehingga akan cenderung menghindari senjangan anggaran. Seseorang dengan self esteem yang tinggi cenderung akan berusaha bekerja dengan baik. Dengan adanya keyakinan tentang kemampuan diri sendiri, memiliki kepuasan diri dan rasa menghormati diri sendiri maka pegawai akan cenderung menghindari senjangan anggaran karena pegawai percaya dengan kemampuannya sendiri sehingga berasumsi anggaran yang dibuat dapat tercapai.

Hasil penelitian ini sesuai dengan temuan Kreitner dan Kinicki (2003) yang menyatakan bahwa orang yang mempunyai self esteem tinggi cenderung memandang diri mereka sendiri sebagai seorang yang penting, berpengaruh, dan berharga dalam suatu pekerjaan yang mereka lakukan. Sebaliknya, orang yang memiliki self esteem rendah akan merasa tidak baik dengan dirinya. Dengan demikian, jika seseorang merasa dirinya begitu penting, berharga, dan berpengaruh maka akan timbul kepercayaan diri atas pekerjaan yang dilakukannya karena apa yang dilakukannya berhasil dan menciptakan hasil yang optimal. Self esteem yang tinggi akan memotivasi manajer penyusun anggaran untuk melakukan pekerjaannya dengan baik untuk menjaga konsistensi hasil evaluasi dirinya agar tetap baik, terlepas dari kondisi asimetri yang mereka peroleh. 


\section{SIMPULAN}

Berdasarkan pembahasan hasil penelitian di atas, dapat disimpulkan bahwa kohesivitas kelompok tidak mampu memoderasi pengaruh partisipasi anggaran pada senjangan anggaran. Kohesivitas kelompok memperlemah pengaruh asimetri informasi pada senjangan anggaran di BPR se-Kota Denpasar. Kohesivitas kelompok memperlemah pengaruh self esteem pada senjangan anggaran di BPR se-Kota Denpasar. Sedangkan saran yang dapat diberikan sebaiknya BPR di Kota Denpasar diharapkan dapat memberikan pelatihan mengenai penyusunan anggaran, atau lebih selektif lagi dalam pemilihan perangkat daerah yang berpartisipasi dalam menyusun anggaran. Bagi para penyusun anggaran di BPR se-Kota Denpasar diharapkan dapat menyampaikan informasi yang sesungguhnya agar tidak ada informasi yang bias antara atasan dan bawahan. Dengan demikian, tujuan organisasi dapat tercapai.

\section{REFERENSI}

Anggraeni, R. S. (2008). Pengaruh Partisipasi Anggaran, Information Asymmetry, dan Budget Emphasis Terhadap Slack Anggaran (Studi Pada PT. Jasa Raharja (Persero) Cabang Daerah Istimewa Yogyakarta). Tesis Universitas Islam Indonesia.

Arthaswadaya, A. (2015). Pengaruh Asimetri Informasi terhadap Budgetary Slack dengan Self Esteem sebagai Variabel Pemoderasi :Studi Eksperimen dalam Konteks Penganggaran Partisipatif. Skripsi Universitas Negeri Yogyakarta.

Brownell, P. (1982). The Role of Accounting Data in Performance Evaluation, Budgetary Partisipative, and Organizational Effectiveness. Journal of Accounting Research, 20, 589-603.

Camman, C. (1976). Effects of the Use of Control System. Accounting, Organizations, and Society, 4, 301-313. 
Chenhall, R., and Morris, D, (1986). The Impact of Structure, Environment and Interdependece on The Perceived Usefulness of Management Accounting System. The Accounting Review LXI, (1), 16-35.

Dubois, B., and Burns, J. A. (1975). An Analysis of the Meaning of Question Mark Response Category in Attitude Scales. Educational and Psychological Measurement, 35(4), 869-884.

Dunk, A. (1993). The Efects of Budget Emphasis and Information Asymmetry on The Relation Between Budgetary Participation and Slack. The Accounting Review, 68(2), 400-410.

Falikhatun. (2008). Interaksi Informasi Asimetri, Budaya Organisasi, dan Group Cohesiveness dalam Hubungan antara Partisipasi Penganggaran dan Budgetary Slack (Studi Kasus pada Rumah Sakit Umum Daerah se-Jawa Tengah). Media Riset Akuntansi, Auditing Dan Informasi, 8(1), 65-84.

Faruq, D. J. (2013). The Effects of Budget Participation, Asymmetric Information, Budget Emphasis, and Organizational Commitment On Budgetary Slack In Pemerintah Kota Pasuruan. Jurnal Ilmiah Mahasiswa Fakultas Ekonomi Dan Bisnis Universitas Brawijaya, 1(1).

Govindarajan, V. (1986). Impact of Participation in The Budgetary Process on Managerial Attitudes an Performance. Universalistic and Contingency Perspetive, 17, 496-516.

Hafsah. (2005). Pengaruh Asimetri Informasi dan Komitmen Organisasi Terhadap Hubungan Anggaran dengan Kesenjangan Anggaran. Tesis Universitas Sumatera Utara. Medan.

Haryanti, I. (2012). Budgetary Participation: How it Affects Performance and Commitment. Accountancy Business and the Public Interest.

Herman, E. (2006). Penganggaran Korporasi: Suatu Pendekatan Terintegratif. Jakarta: PT Raja Grafindo Persada.

Ikhsan, A dan Ishak, M. (2005.) Akuntansi Keperilakuan. Jakarta: Salemba Empat.

Karsam. (2013). The Influence of Participation in Budgeting on Budgetary Slack with Information Asymmetry as a Moderating Variable and its Impact on the Managerial Performance. International Journal of Applied Finance and Business Studies, 1(1), 28-38. 
Kartika, A. (2010). Pengaruh Komitmen Organisasi dan Ketidakpastian Lingkungan dalam Hubungan antara Partisipasi Anggaran dengan Senjangan Anggaran. Jurnal Kajian Akuntansi, 2(1), 39-60.

Kim, S. Y., and Robert, T. (2001). A LMX Model: Relating Multi Level Antecedent to the LMX Relationship and Citizenship Behaviour. The Midwest Academy of Management Association Cenference.

Kreitner, R., dan Kinicki, A. (2003). Perilaku Organisasi (1st ed.). Jakarta: Salemba Empat.

Lestari, N. K. T. (2014). Pengaruh Penganggaran Partisipatif pada Senjangan Anggaran dengan Ketidakpastian Lingkungan dan Komitmen Organisasi sebagai Variabel Pemoderasi. Skripsi Fakultas Ekonomi dan Bisnis Universitas Udayana.

Lowe, E., and Shaw, R. (1968). An Analysis of Managerial Biasing: Evidence From a Company's Budgeting Proses. The Journal of Management Studies, 304-315.

Lukka, K. (1988). Budgetary Biasing in Organizations: Theoritical Framework and Empirical Evidence. Accounting, Organization, and Society, 13, 281301.

Mahadewi, Sagung S. 2014. Pengaruh Partisipasi Penganggaran pada Senjangan Anggaran dengan Asimetri Informasi dan Komitmen Organisasi sebagai Pemoderasi.E-Jurnal Akuntansi Universitas Udayana, 8 (3), pp: 458-473.

Merchant, K. (1985). Budgeting and Propersity to Create Budgetary Slack. Accounting, Organization, and Society, 10, 201-210.

Otley. (1980). The Contingency Theory of Management Accounting: Acheivement and Prognosis. Accounting, Organizations and Society, 422.

Onsi, M. (1973). Factor Analysis of Behavioral Variables Affecting Budgetary Slack. The Accounting Review, 48, 535-538.

Paingga, R. (2013). Pengaruh Partisipasi Penganggaran dan Asimetri Informasi Terhadap Timbulnya Budgetary Slack (Studi Empiris Pada Pemerintah Kota Padang). Skripsi Fakultas Ekonomi Universitas Negeri Padang.

Pratiwi, P. L. (2008). Pengaruh Partisipasi dalam Penyusunan Anggaran, Asimetri Informasi, Penekanan Anggaran, dan Komitmen Organisasi terhadap Slack Anggaran (Studi Kasus pada BPR-BPR di Kecamatan Kuta). Skripsi Fakultas Ekonomi Universitas Udayana. 
Putranto, Y. A. (2012). Pengaruh Moderasi Informasi Asimetridan Group Cohesiveness terhadap Hubungan Partisipasi Penganggaran dengan Budgetary Slack. Jurnal Economia, 8(2).

Rahmiati, E. (2013). Pengaruh Partisipasi Anggaran terhadap Senjangan Anggaran dengan Asimetri Informasi dan Komitmen Organisasi sebagai Pemoderasi. Skripsi Fakultas Ekonomi Universitas negeri Padang.

Robbins, S. (1996). Perilaku Organisasi. Jakarta: PT Prenhallindo.

Siegel, G., and Marconi, H. R. (1989). Behavioral Accounting. South Western Publishing Co.

Soobaroyen, T. (2005). Management Control System and Dysfunctional Behaviour : An Emprical Investigation. United Kingdom: University of Wales, Aberystwyth.

Stevens, D. E. (2002). The Effects of Reputation and Ethics on Budgetary Slack. Journal of Management Accounting Research, 14.

Sulistyaningsih, F. C. (1995). Pengaruh Self Esteem Terhadap Kemampuan Berpikir Kreatif Dan Sikap Kreatif Remaja. Skripsi Fakultas Psikologi Universitas Gajah Mada Yogyakarta.

Sukarno, E. (2000). Sistem Pengendalian Manajemen: Suatu Pendekatan Praktis. Jakarta: PT Gramedia Pustaka Utama.

Syahrir, A. D. (2017). Pengaruh Penganggaran Partisipatif Terhadap Budget Slack dengan Sikap sebagai Variabel Moderating. Jurnal Infestasi, 13(1), 243-252.

Wardani, N. K. M. (2014). Budgetary Slack dalam Penganggaran Perusahaan: Tipu Muslihat Sang Aktor. Universitas Pendidikan Ganesha Singaraja.

Wenny, S. (2012). Pengaruh Budgetary Participation, Information Asymmetry, Budget Emphasis, dan Self Esteem Terhadap Budgetary Slack. Skripsi Fakultas Ekonomi Universitas Tarumanegara.

Widhiarso, W. (2010). Pengembangan Skala Psikologi : Lima Kategori Respons ataukah Empat Kategori Respons?. Jurnal Fakultas Psikologi Universitas Gadjah Mada, 1-5.

Winarni, T. T. (2014). Analisis Pengaruh Partisipasi Anggaran, Budget emphasis, dan Informasi Asimetris terhadap Slack Anggaran (Studi pada Satuan Kerja Pemerintah Daerah Kabupaten Wonogiri). Naskah Publikasi Universitas Muhammadiyah Surakarta. 
Nyoman Putra Yuna Aditya dan Made Gede Wirakusuma. Kohesivitas ...

Young, S. (1985). Participative Budgeting: The Effects of Risk Aversion and Symmetric Information on Budgeting Slack. Journal of Accounting Research, 23(2), 829-842. 